D>

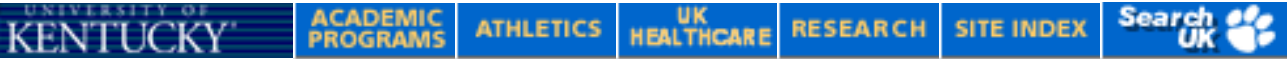

Date: 26 October 1994

\section{Subject: Farmer Struck by Truck and Killed on Public Roadway}

\begin{abstract}
SUMMARY
A 63-year-old farmer was fatally injured after being struck by a truck while transporting hay to his farm. After loading five round bales of hay onto a flat bed wagon the victim drove his tractor down a public roadway to transfer the hay to another pasture for winter storage. The wagon and tractor did not have Slow Moving Vehicle (SMV) emblems, Roll Over Protective Structures (ROPS) or a seat belt. After driving down a highway about one quarter of a mile, a two-ton log truck struck the back of his flat bed wagon. The tractor rolled over and the victim suffered massive skull injuries when he was thrown from the tractor. A witness who was traveling by car in the opposite direction called 911 to summon help. The victim was pronounced dead at the scene by the coroner. In order to prevent future fatalities of this type, the FACE investigator recommends:
\end{abstract}

- Tractors should be retro-fitted with ROPS and a seat belt.

- All equipment should be clearly marked with a Slow Moving Vehicle (SMV) emblem while driving on public roadways.

- Transportation of harvest products on public roadways should be followed by a trailing unit to warn drivers.

\section{INTRODUCTION}

On September 16, 1994, a 63-year-old tractor driver was killed on a public roadway after being stuck from behind by a truck. On September 17, 1994, the FACE investigator read of the incident in a local newspaper. On September 24, 1994, the FACE investigator traveled to the scene where he interviewed the coroner and EMS personnel. Photographs of the scene and tractor were made for documentation. The State Police, equipment manufacturer and the reconstruction specialist with the State Police were interviewed later.

The victim was a full-time, life-long farmer, presently operating a 230 acre farm. He raised tobacco, cattle and some hay. He had lived at the same location all his life He often hired seasonal help as needed to complete specific tasks. He had had only a few minor injuries in the past as a result of his work. The victim's driver's license expired in 1993.

\section{INVESTIGATION}

About mid-day on Friday, September 16, the victim had loaded five round bales of hay onto a flat bed wagon. He was to transport the bales to another field 4 miles away for storage. Having loaded the bales, the victim turned left onto a public highway heading north from a private drive. After about one-quarter mile the 
highway curved slightly to the left and proceeded down a gentle slope. The 22 foot wide asphalt smooth surface road had narrow shoulders. The right side of the road while traveling in a northerly direction falls over a steep embankment. The left side has a small drainage ditch, then an upward sloping bank.

The 1977 John Deere 2040 tractor (40 horse power pto) was not ROPS-equipped. There was no seat belt, SMV emblem, PTO guard, wheel weights or front end weights. The tires were air filled. The hour meter read 2085.35. The gross weight was 4000 pounds.

The victim, working alone the day of the incident, proceeded northward down the highway on this warm, sunny, clear day. Pulling the loaded wagon it is estimated he was traveling between 10 and $14 \mathrm{MPH}$. A two-ton log truck pulling a chipper crested the hill and caught sight of the rear of the wagon. The driver of the truck also saw a car approaching in the southbound lane. To avoid a head-on collision, the driver of the truck hit the rear of the hay-loaded wagon. The estimated speed of the truck was $55 \mathrm{MPH}$. The impact caused the bed of the wagon (sled) to move forward off the wagon frame and strike the rear tires and fenders on the tractor. The tractor jackknifed, rolled over to its side and slid northward in the southbound lane, and then turned over again and came to rest upside down partly on the road and partly on the west side of the road. The victim was thrown from the tractor. He landed on the asphalt near the rear of the upside down tractor. He sustained massive head injuries in the incident. The tractor seat released from the tractor on impact and landed about 12 feet beyond the victim.

The witness who was southbound saw the incident in her rearview mirror and returned to the scene. The call came into 911 at 1:10 pm. The ambulance arrived at 1:18. The coroner pronounced the victim dead at 1:25 pm at the scene.

The tractor was severely damaged in the incident. Damage to the rear wheels suggest the tractor rolled over one and one half rotations. The hood was scraped, exhaust broken, gear shift broken off. The top point of the three point hitch was bent. The fenders were severely contorted from the rear impact of the wagon and the rolling/sliding action on the asphalt.

The wagon frame was completely destroyed. The front and rear axles were separated, and the sled was separated from the frame. Two of the 15" tires were flattened. The oak sled was in one piece except the rear gate/guard was broken off and there was a small break on the front board where the sled hit the tractor fender. The wagon surface measured twenty-one feet by twelve feet. It was made of 1.25 inch white oak. The rear guard was extended 40 inches above the wagon surface. It was broken off in the impact. The wagon surface was 28 inches above the road surface.

The round bales flew off the wagon during the incident. They measured 4 foot 8 inches high and 41 inches long. They were damaged in the incident. The 1969 International single axle log truck suffered moderate damage in the incident.

\section{CAUSE OF DEATH}

The cause of death was listed as fractured neck as well as other internal injuries.

\section{RECOMMENDATIONS/DISCUSSION}

Recommendation \#1: Tractor owners and operators should contact their county extension agent, local equipment dealer, or equipment manufacturer to see if retro-fit rollover protection and operator restraint systems are available for this equipment. 
Discussion \#1: The tractor in this incident, manufactured in 1977, was not equipped with a ROPS or an operator restraint system, which protects the operator in the event of a roll over. ROPS first became available as optional equipment on farm tractors in 1971. These safety features were not required on tractors until 1976, when OSHA standard 29CFR 1928.51 went into effect. This standard required employers to provide ROPS and safety belts for all employee-operated tractors manufactured after October 25, 1976. However, this standard does not apply to family farms or farms employing fewer than 11 employees. Since 1985, as a result of voluntary agreements by tractor manufacturers, all new tractors sold in the US have been equipped with ROPS and safety belts. (MMWR Jan.29, 1993) On this 1977 tractor, retro-fit ROPS and operator restraint systems are available. The manufacturer of this particular tractor provides the ROPS at $\$ 375.00$ and dealers sell them at cost. Tractor owners should contact dealers, manufacturers or county extension agents for information on sources of retro-fit ROPS and operator restraint systems. Although ROPS and a seat belt would not likely have prevented injury in this case, they might have prevented death as a result of the injuries.

Recommendation \#2: All equipment, including nonmotorized equipment, should have clearly marked SMV emblems attached to the rear.

Discussion \#2: Although the speed of the truck and the oncoming traffic were factors in this incident, clearly marked slow moving vehicle identification may have provided early enough warning to the truck driver to slow the truck. Curving roads and hills create blind spots for drivers. The well-recognized SMV symbol may provide the extra warning necessary to avoid a disaster.

Recommendation \#3: Transporters of harvest products on public roadways where hills and curves obscure vision should be followed by a trail vehicle to warn drivers who approach from the rear.

Discussion \#3: To facilitate early warning, a vehicle such as a pick up truck with emergency lights flashing should follow the slow moving vehicle. Especially on curvy roads, this trailing vehicle would warn traffic approaching from the rear.

\section{REFERENCES}

Standard Number 1928.51 Subpart C US Department of Labor Occupational Safety and Health Administration, OSHA CD-ROM (OSHA A94-2) February 1994.

Effectiveness of Roll Over Protective Structures for Preventing Injuries Associated with Agricultural Tractors. MMWR 42 (03); 57-59.

National Safety Council (1978). "Tractor Operation and Roll-Over Protective Structures." Occupational Safety \& Health Data Sheets. I-622-Reaf. 85.

National Institute for Occupational Safety and Health (Jan 29, 1993). "NIOSH Reports on the Preventability of Tractor Rollovers." Centers for Disease Control and Prevention. DHHS(NIOSH) publication No. 93-119. 